\title{
Development Of Pesoktren's Business Architecture
}

\author{
Anggi Jihan Putri ${ }^{1}$, Chusnatun Nisa ${ }^{2}$, Ardania Safitri ${ }^{3}$, Muhammad Ainul Yaqin ${ }^{4}$ \\ 1,2,3,4 Jurusan Teknik Informatika, Fakultas Sains dan Teknologi, Universitas Islam Negeri (UIN) \\ Maulana Malik Ibrahim Malang \\ Email: ${ }^{1} 16650004 @$ student.uin-malang.ac.id, ${ }^{2} 16650025 @$ student.uin-malang.ac.id, \\ 16650027@student.uin-malang.ac.id, ${ }^{4}$ yaqinov@ti.uin-malang.ac.id
}

\begin{abstract}
Abstrak-Teknologi merupakan suatu hal yang sangat dibutuhkan untuk saat ini. Salah satunya teknologi juga diperlukan di pondook pesantren. Pondok pesantren saat ini belum memiliki arsitektur yang jelas untuk mengembangkan teknologi. Pada suatu lembaga, perlu sebuah perencaan yang matang untuk pengembangan arsitektur. Untuk menunjang keberhasilan pada pondok pesantren maka dibutuhkan sebuah proses bisnis yang baik. Untuk mewujudkanya maka dibuatlah arsitektur bisnis pondok pesantren menggunakan metode TOGAF ADM. Pada pembuatan arsitektur bisnis ini mengacu pada 52 standar pondok pesantren. Dari 52 standar pondok pesantren, masing-masing akan dibuat SOP lalu dikelompokkan masing-masing SOP menggunakan algoritma TF-IDF dan artikata untuk memudahkan proses pengelompokkan SOP sehingga di dapatkan sebuah struktur organisasi pondok pesantren.
\end{abstract}

Kata Kunci-Pondok Pesantren, Model Proses Bisnis, TOGAF ADM, SOP, Struktur Organisasi

Abstrac-Technology is a thing that is needed for now. One of them is technology that is also needed in Islamic boarding schools. Islamic boarding schools currently do not have a clear architecture for developing technology. In an institution, it needs a mature planning for architectural development. To support the success of Islamic boarding school, a good business process is needed. To make this happen the pesantren business architecture was created using the TOGAF ADM method. In making this business architecture refers to 52 boarding school standards. Of the 52 boarding school standards, each SOP will be made and then grouped each SOP using the TF-IDF algorithm and articulation to facilitate the process of grouping SOPs so that an organizational structure of the boarding school is obtained.

Keyword- Islamic boarding school, Business Process Model, TOGAF ADM, SOP, Organizational structure

\section{PENDAHULUAN}

Pondok pesantren adalah suatu lembaga pendidikan sekaligus lembaga dakwah Islam yang ada di Indonesia, pada dasarnya pesantren dibangun atas keinginan bersama antara dua komunitas yang saling bertemu yaitu santri (masyarakat) yang ingin menimba ilmu sebagai bekal hidup dan kyai/guru yang secara ikhlas ingin mengajarkan ilmu dan pengalamannya. Seperti yang dikatakan oleh Imam Tholkhah dan Ahmad Barizi di dalam bukunya membuka jendela pendidikan, "Kyai dan santri adalah dua komunitas yang memiliki kesadaran yang sama untuk sacara bersama-sama membangun komunitas keagamaan yang disebut pesantren".

Pesantren di Indonesia baru diketahui keberadaan dan perkembangannya setelah abad ke 16. Karya-karya jawa klasik seperti serat cabolek dan serat centini mengungkapkan bahwa sejak permulaan abad ke 16 di Indonesia telah banyak di jumpai lembaga-lembaga yang mengajarkan berbagai kitab Islam klasik dalam bidang fiqih, aqidah, tasawuf, dan menjadi pusatpusat penyiaran Islam yaitu pesantren.

Pondok Pesantren saat ini kebanyakan belum mempunyai arsitektur yang jelas untuk pengembangan pada bidang Teknologi Informasi sehingga langkah-langkah dalam pengembangannya masih belum terpetakan dan pengerjaannya yang tumpang tindih. Dengan adanya arsitektur yang benar maka dalam membangun sistemnya akan mengurangi resiko 
duplikasi sistem, tidak kompatibel, ambigu dan membutuhkan biaya yang tidak perlu baik untuk integrasi maupun pemeliharaannya.

Teknologi informasi suatu lembaga harus dibangun dengan perencanaan yang matang. Kurangnya perencanaan di dalam proses pengembangan teknologi informasi yang tepat akan menghambat arah strategi bisnis suatu lembaga dalam mencapai tujuannya. Teknologi informasi yang baik, melihat dari berbagai sudut pandang dalam suatu pengembangan sistem, dimulai dari mendefinisikan arsitektur data, arsitektur aplikasi serta mendefinisikan arsitektur teknologi yang mendukung jalannya teknologi informasi tersebut.

Dalam menunjang keberhasilan kegiatan dalam pondok pesantren maka dibutuhkan proses bisnis yang baik. Menurut Mathias weske dalam bukunya business Process Management Concepts, Languages, Architectures tahun 2012, proses bisnis adalah sebuah kumpulan aktivitas yang dijalankan secara koordinasi didalam lingkungan organisasional dan lingkungan teknis. Aktivitas-aktivitas ini bersama-sama mencapai tujuan bisnis. Setiap proses bisnis ditetapkan oleh satu organisasi (bagian), namun dapat berinteraksi dengan proses yang dijalankan organisasi (bagian) lain.

Dalam penelitian ini Pondok menggunakan TOGAF ADM sebagai standar dalam pengembangan arsitektur enterprise karena TOGAF ADM merupakan metode yang kompleks dan mudah di implementasikan berdasarkan kebutuhan banyak organisasi, baik organisasi industri ataupun industri akademik. Sehingga didapatkan gambaran yang jelas bagaimana melakukan perancangan arsitektur enterprise yang baik dan sesuai dengan organisasi.

\section{TINJAUAN PUSTAKA}

\subsection{Pengertian Pesantren}

Pesantren adalah asrama tempat pendidikan tradisional, dimana para siswa-siswinya semua tinggal bersama dan belajar di bawah bimbingan guru yang lebih dikenal dengan sebutan Kyai dan mempunyai asrama untuk tempat menginap santri. Pesantren terdiri dari kata "santri" yang ditambahkan dengan imbuhan "pe" dan akhiran "an". Kata lain "santri" menurut A.H Johns berasal dari Bahasa Tamil yang berarti guru mengaji. Sedangkan istilah santri digunakan untuk penyebutan siswa-siswi di pondok pesantren. Pondok pesantren adalah lembaga pendidikan Islam tertua yang merupakan produk budaya di Indonesia. Keberadaan Pesantren di Indonesia dimulai sejak Islam masuk negeri ini dengan mengadopsi sistem pendidikan keagamaan yang sebenarnya telah lama berkembang sebelum kedatangan Islam. Pondok pesantren sebagai lembaga pendidikan yang telah lama berkembang di negeri ini yang diakui memiliki andil yang sangat besar terhadap perjalanan sejarah bangsa.

\subsection{Arsitektur Bisnis}

Arsitektur bisnis secara umum menggambarkan kumpulan aktivitas bisnis, data dan informasi yang ada dalam lingkungan internal dan eksternal organisasi. Arsitektur bisnis adalah representasi formal dan tools serta informasi bagi profesional bisnis organisasi dalam menilai, merubah, dan merancang bisnis. Arsitektur bisnis juga menunjukkan relasi atau hubungan antara: aktivitas, kemampuan, fungsi, proses, waktu, urutan proses, sumber daya, orang, ketergantungan, kebutuhan, kolaborasi, organisasi, lokasi, batasan, data, sistem, peralatan, biaya, kontrol, keputusan, rules, keputusan, alur bisnis, aktivitas manual dan otomatis, transaksi, perbedaan, dan kemungkinan.

Konseptual pemodelan arsitektur dalam enterprise architecture dipengaruhi oleh 3 (tiga) lapisan/layer utama, yaitu business layer, application layer dan technology layer. Di dalam business layer akan mengambarkan tiga aspek, yaitu struktur, perilaku dan informasi. Ke tiga aspek ini sangat berperan penting dalam pemodelan bisnis, karena dalam pemodelan bisnis akan memperlihatkan hubungan dari perilaku organisasi dengan informasi yang dibutuhkan, dan hubungan relasi yang terjadi di dalam struktur organisasi, sehingga arsitektur bisnis merupakan hal utama yang harus didefinisikan secara lengkap sebelumnya di lanjutkan pada tahapan berikutnya.

Menurut Ralph Whittle dan Conrad Myrick (2004), arsitektur bisnis dalam enterprise tersebut bisa dihubungkan dengan semua komponen yang ada dalam pengembangan enterprise architecture, hal ini bisa dilihat pada Gambar 1. 


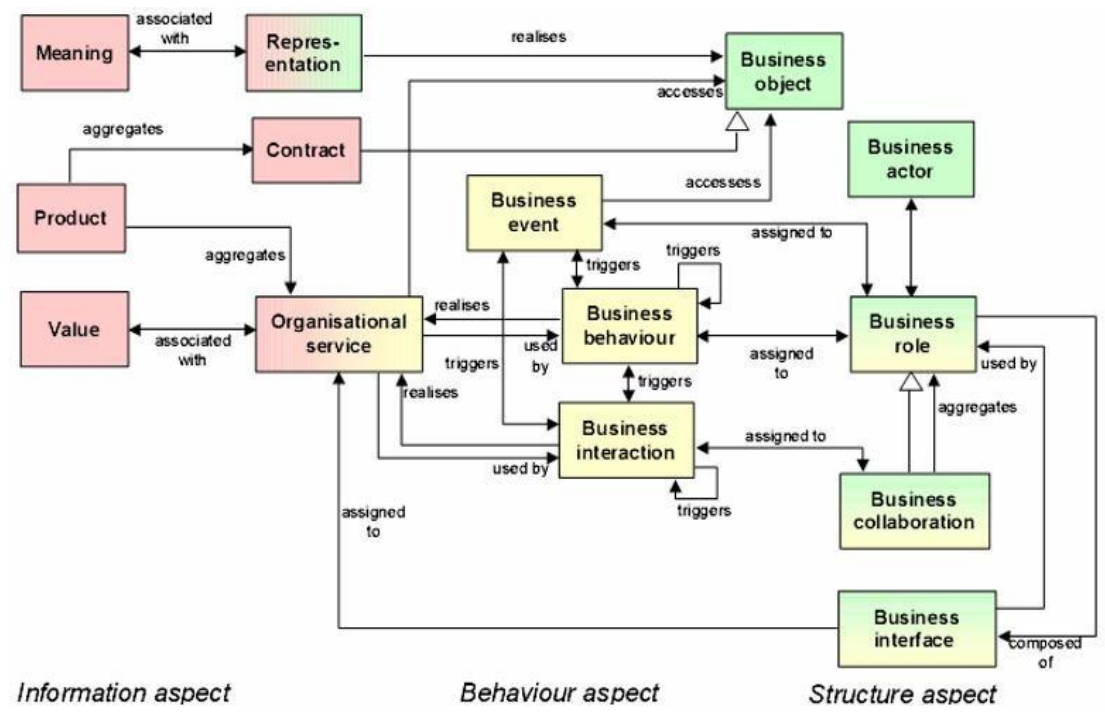

Gambar 1. Model Lapisan Bisnis

\subsection{Bottom Up}

Pada penelitian ini pendekatan yang digunakan pada Arsitektur Bisnis adalah BottomUp, yaitu memulai penelitian dari urutan bawah ke urutan atas dimulai dari Prosedur Operasi Baku/Standar Operasional Prosedur (SOP).

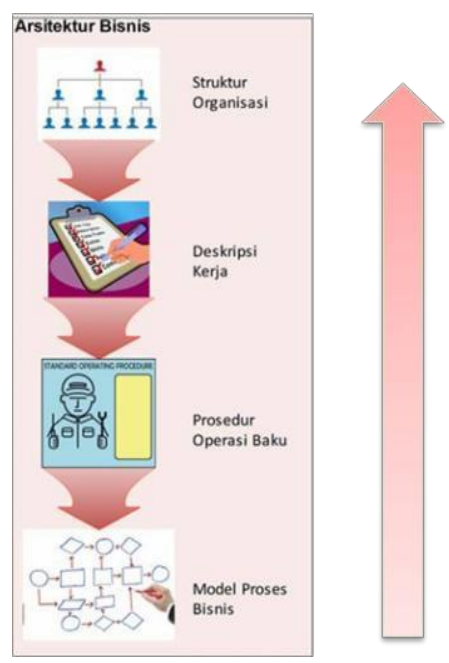

Gambar 2. Bottom UP

\section{METODE PENELITIAN}

Prosedur penelitian ini menjelaskan bagaimana pelaksanaan penelitian. Tahap penelitian yang dilakukan sebagai berikut. 


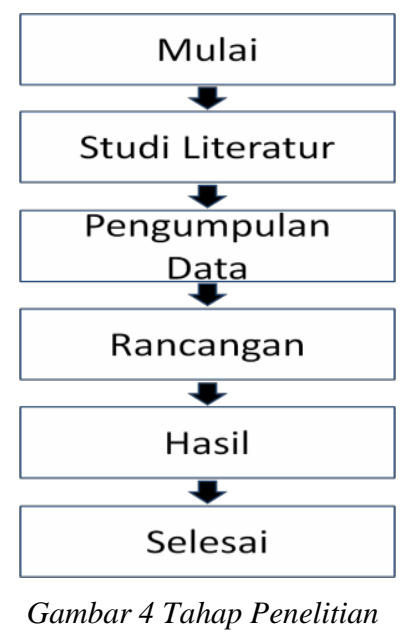

\subsection{Pengumpulan Data}

Data yang dibutuhkan dalam pengembangan arsitektur bisnis pondok pesantren berdasarkan kebutuhan pondok pesantren dalam memanfaatkan IT secara maksimal sehingga dapat berjalan lebih efektif dan cepat dalam mengambil keputusan.

Data yang diambil pada penelitian ini adalah data sekunder yang menggunakan metode kulitatif karena menganalisis kebutuhan pondok pesantren berdasarkan 52 standart. Metode ini dilakukan dengan cara mengumpulan data dan informasi dari penelitian terkait sebelumnya dan dari berbagai sumber seperti jurnal, buku, serta artikel yang terkait dengan penelitian.

\subsection{Analisis Data}

Analisis data pada penelitian ini yaitu analisis dari 52 standar nasional pondok pesantren untuk dijadikan sebuah Standar Operasional Prosedur (SOP) yang digunakan sebagai acuan dalam pembuatan model proses setiap proses bisnis yang ada pada pondok pesantren.

\subsection{Perancangan Proses Bisnis}

Perancangan proses bisnis dalam penelitian ini yaitu membuat proses bisnis pada pondok pesantren yang sesuai dengan 52 standar nasional pondok pesantren berdasarkan standar operasioanl prosedur (SOP) dari setiap proses bisnis/kegiatan yang terdapat dalam pondok pesantren. Didalam proses bisnis berisi tentang kejadian-kejadian yang dilakukan mulai awal hingga akhir terjadinya suatu proses bisnis atau kegiatan.

\subsection{Pengujian}

Pengujian yang dilakukan dalam penelitian ini yaitu dengan mengujikan setiap proses bisnis yang telah dibuat untuk di implementasikan pada proses bisnis pondok pesantren. Pengujian ini dilakukan untuk mengetahui seberapa efektif dan efisien proses bisnis pondok pesantren, serta bagaimana dampak perubahan proses bisnis yang ada pada pondok pesantren sebelum dan sesudah dibuatnya model proses bisnis.

\section{HASIL DAN PEMBAHASAN}

4.1. artikata.com

artikata.com merupakan salah satu situs website yang berfungsi untuk mencari makna kata yang sama. Pada penelitian ini, peneliti menggunakan website ini untuk mencari kesamaan makna kata yang terdapat pada SOP yang telah dibuat. 


\subsection{Algoritma TF-IDF}

Algoritma TF-IDF (Term Frequency - Inverse Document Frequency) merupakan algoritma yang digunakan untuk melakukan analisa antar kalimat. Pada penelitian ini algoritma ini diterapkan untuk mengelompokkan kata/kalimat yang sama. Hal ini dilakukan untuk memudahkan dalam pengelompokan SOP yang telah dibuat.

\section{3. $\quad$ Model Proses Bisnis/SOP ( Standart Operating Procedure)}

Tabel 1. Daftar SOP dan pengelompokkan

\begin{tabular}{|c|c|c|}
\hline No. & Nama Model Proses/SOP & Deskripsi \\
\hline 1. & Cara-cara penyampaian informasi pada santri, orang tua, dan staff & Sekretariatan \\
\hline 2. & Pelaporan terjadinya bullying & Ketertiban \\
\hline 3. & Pelaporan terjadinya pelecehan & Ketertiban \\
\hline 4. & Penunjukan petugas perlindungan anak & Sekretariat \\
\hline 5. & Pelaporan siswa yang hilang dari pondok pesantren & Sekretariat \\
\hline 6. & Pelaporan pelanggaran santri & Ketertiban \\
\hline 7. & Majelis tahkim & Kegiatan Pondok \\
\hline 8. & Pelaporan penindakan & Ketertiban \\
\hline 9. & Pelaporan prestasi santri & Sekretariat \\
\hline 10. & Rapat untuk memutuskan hukuman & Ketertiban \\
\hline 11. & Pengaduan dan keluhan dari santri dan orangtua & Sekretariat \\
\hline 12. & Pendidikan kesehatan terkait dengan miras dan narkoba & Kegiatan Pondok \\
\hline 13. & $\begin{array}{l}\text { Catatan kesehatan tentang riwayat penyakit dan alergi sebelum } \\
\text { masuk pondok pesantren }\end{array}$ & Kesehatan \\
\hline 14. & Catatan kesehatan selama di pondok pesantren & Kesehatan \\
\hline 15. & Organisasi kepengurusan pondok pesantren & Ekstrakurikuler \\
\hline 16. & Prosedur penanganan masalah & Pembinaan \\
\hline 17. & $\begin{array}{l}\text { Prosedur penanganan krisis (wabah, kebakaran, kecelakaan, } \\
\text { masalah serius lainnya) }\end{array}$ & Ekstrakurikuler \\
\hline 18. & Pemisahan asrama untuk kelompok umur yang berbeda & Logistik \\
\hline 19. & Kesehatan dalam hal fasilitas & Kesehatan \\
\hline 20. & Waktu luang yang cukup & Kegiatan pondok \\
\hline 21. & Pilihan kegiatan di waktu luang & Kegiatan pondok \\
\hline 22. & $\begin{array}{l}\text { Akses yang memadai pada fasilitas yang digunakan untuk kegiatan } \\
\text { di waktu luang }\end{array}$ & Logistik \\
\hline 23. & Pengawasan yang memadai pada kegiatan-kegiatan tersebut & Ketertiban \\
\hline 24. & $\begin{array}{l}\text { Adanya senat santri sebagai perwakilan untuk menyampaikan } \\
\text { pendapat }\end{array}$ & Sekretariat \\
\hline 25. & Penunjukan kepala staf & Sekretariat \\
\hline 26. & Konseling & Kegiatan Pondok \\
\hline 27. & prosedur pertolongan pertama & Kesehatan \\
\hline 28. & prosedur pemeriksaan kesehatan berkala & Kesehatan \\
\hline 29. & Pencatatan riwayat kesehatan dipondok pesantren & Kesehatan \\
\hline 30. & Prosedur rujukan ke rumah sakit & Kesehatan \\
\hline 31. & Prosedur pendampingan santri yang dirawat di rumah sakit & Kesehatan \\
\hline 32. & Prosedur pengambilan obat dengan resep dan tanpa resep dokter & Kesehatan \\
\hline 33. & Prosedur pengelolaan persediaan obat & Kesehatan \\
\hline 34. & Pelaporan obat dan keluhan penyakit & Kesehatan \\
\hline 35. & Prosedur persetujuan orangtua santri pada tindakan medis & Sekretariat \\
\hline 36. & Prosedur perawatan santri yang sakit secara berkala & Kesehatan \\
\hline 37. & Presedur perawatan gawat darurat santri yang sakit & Kesehatan \\
\hline 38. & Prosedur penjagaan santri yang dirawat inap & Kesehatan \\
\hline
\end{tabular}




\begin{tabular}{|c|c|c|}
\hline 39. & Prosedur konsultasi kesehatan & Kesehatan \\
\hline 40. & Prosedur konsultasi psikologis & Kesehatan \\
\hline 41. & Prosedur pembuatan rencana perawatan kesehatan santri & Kesehatan \\
\hline 42 . & $\begin{array}{l}\text { Prosedur perawatan santri dengan penyakit khusus seperti asma dan } \\
\text { penyandang cacat }\end{array}$ & Kesehatan \\
\hline 43. & Prosedur menangani kasus diskriminasi & Ketertiban \\
\hline 44. & Prosedur menghubungi dan dihubungi orang tua & Sekretariat \\
\hline 45. & Prosedur kunjungan orangtua & Sekretariat \\
\hline 46. & Prosedur Mengirim dan menerima surat & Sekretariat \\
\hline 47. & Prosedur pemberitahuan pada orangtua & Sekretariat \\
\hline 48. & Prosedur call center pondok pesantren & Sekretariat \\
\hline 49. & Prosedur penyimpanan barang-barang pribadi santri & Logistik \\
\hline 50. & Prosedur penyimpanan dan distribusi uang saku santri & Sekretariat \\
\hline 51. & Prosedur pengenalan dan pengasuhan santri & Sekretariat \\
\hline 52. & Prosedur penunjukan wali pendidikan & Sekretariat \\
\hline 53. & $\begin{array}{l}\text { Prosedur pemantauan catatan santri oleh pengasuh pondok } \\
\text { pesantren dan tindakan-tindakan yang telah dilakukan }\end{array}$ & Keamanan \\
\hline 54. & Prosedur belanja bahan makanan & Logistik \\
\hline 55. & Prosedur penyimpanan bahan makanan & Konsumsi \\
\hline 56. & Prosedur memasak makanan & Konsumsi \\
\hline 57. & Prosedur Penyajian makanan & Konsumsi \\
\hline 58. & Prosedur pemantauan kebersihan dan gizi makanan & Konsumsi \\
\hline 59. & $\begin{array}{l}\text { Prosedur penyajian makanan ringan dan air minum di luar jam } \\
\text { makan }\end{array}$ & Konsumsi \\
\hline 60. & Prosedur pelatihan kebakaran & Ekstrakurikuler \\
\hline 61. & Prosedur pencegahan kebakaran & Ekstrakurikuler \\
\hline 62. & Perosedur Penugasan Khusus Pada Santri & Logistik \\
\hline 63. & $\begin{array}{l}\text { Prosedur pondok pesantren menanggung beban sosial bagi anak- } \\
\text { anak disekitar pondok pesantren }\end{array}$ & Humas \\
\hline 64. & Prosedur penyelenggaraan kegiatan berisiko tinggi & Kegiatan pondok \\
\hline 65. & Prosedur seleksi peserta kegiatan berisiko tinggi & Kegiatan pondok \\
\hline 66. & Prosedur penyampaian informasi dari dunia luar pondok pesantren & Humas \\
\hline 67. & Prosedur pengawasan wilayah pondok pesantren & Keamanan \\
\hline 68. & Penjadwalan pengawas santri di luar pondok pesantren & Ketertiban \\
\hline 69. & Prosedur pengawasan santri di luar pondok pesantren & Keamanan \\
\hline 70. & Penjadwalan piket di malam hari & Keamanan \\
\hline 71. & Prosedur pengawasan di malam hari & Keamanan \\
\hline 72. & Prosedur penugasan dan deskripsi kerja pada staf & Humas \\
\hline 73. & Prosedur pengenalan lingkungan dan pelatihan bagi staf baru & Humas \\
\hline 74. & Prosedur perekrutan staf & Sekretariat \\
\hline 75. & Prosedur karir staf & Sekretariat \\
\hline 76. & Pembuatan buku pedoman pelaksanaan tugas & Sekretariat \\
\hline 77. & Prosedur pengasuh santri & Pembinaan \\
\hline 78. & Prosedur privasi santri (untuk beberapa kasus) & Keamanan \\
\hline 79. & Prosedur pemeriksaan dan seleksi staf & Ketertiban \\
\hline 80. & Prosedur kontak dengan santri & Sekretariat \\
\hline 81. & Prosedur kelayakan asrama di pondok pesantren & Logistik \\
\hline 82. & Prosedur akses dan keamanan asrama di pondok pesantren & Keamanan \\
\hline 83. & Prosedur kelayakan kamar tidur santri & Logistik \\
\hline 84. & Prosedur kelayakan tempat belajar mandiri & Logistik \\
\hline 85. & Prosedur penggunaan toilet & Logistik \\
\hline 86. & Prosedur penggunaan ruang cuci & Logistik \\
\hline 87. & Prosedur kelayakan toilet & Logistik \\
\hline 88. & Prosedur kelayakan ruang cuci & Logistik \\
\hline 89. & Prosedur pengganti fasilitas & Logistik \\
\hline 90. & Prosedur penggunaan ruang ganti & Logistik \\
\hline
\end{tabular}




\begin{tabular}{|l|l|l|}
\hline 91. & Prosedur penyelenggaraan kegiatan di area rekreasi & Humas \\
\hline 92. & $\begin{array}{l}\text { Prosedur penjaminan keamanan santri dari bahaya di dalam pondok } \\
\text { pesantren }\end{array}$ & Keamanan \\
\hline 93. & Prosedur kelayakan ruang isolasi untuk santri yang sakit & Logistik \\
\hline 94. & Prosedur pencucian & Logistik \\
\hline 95. & Prosedur penyimpanan barang-barang pribadi & Keamanan \\
\hline 96. & Prosedur penyediaan barang-barang keperluan pribadi & Logistik \\
\hline 97. & Prosedur pengaturan pemondokan bagi santri & Sekretariat \\
\hline 98. & Prosedur pertukaran pelajar santri & Sekretariat \\
\hline
\end{tabular}

4.4. Job Desc

1. Keamanan, Ketertiban dan Pembinaan

a. Mencatat tindakan pelanggaran yang dilakukan oleh santri

b. Menentukan tindakan yang cocok diberikan kepada santri sesuai dengan pelanggaran yang dilakukan

c. Memberi tindakan (hukuman) kepada santri yang melakukan pelanggaran

d. Memastikan seluruh santri mengikuti kegiatan yang dijadwalkan oleh pondok pesantren

e. Menyampaikan prosedur penyimpanan barang kepada santri

f. Melakukan pemeriksaan terhadap calon staff

g. Melakukan pengawasan di malam hari

h. Melakukan piket secara bergantian untuk melakukan jaga setiap malam hari

i. Melakukan pengawasan dan menjadwalkan secara bergilir untuk santri yang ada di luar pondok pesantren

j. Melakukan pemantauan terhadap catatan santri yang bermasalah

k. Memberikan tindakan pada kasus diskriminasi

1. Melakukan pengawasan terhadap santri (selama kegiatan)

m. Memutuskan hukuman yang diberikan kepada santri yang melanggar ketentuan

n. Memberikan tindakan berupa hukuman kepada santri yang melanggar

2. Humas

a. Menghubungi fasilitator, dan pemateri yang akan mengisi materi untuk santri

b. Menjadi penghubung antara pihak pondok pesantren dengan pihak luar pondok pesantren untuk melakukan komunikasi

c. Menghubungi orang tua santri saat santri memiliki kendala

d. Menghubungi pihak terkait saat santri melakukan kegiatan diluar pondok pesantren

e. Menjelaskan penugasan kepada staff dan santri baru

f. Menjadi perantara anatara lingkungan pondok pesantren dengan pondok pesantren

3. Kesehatan

a. Memberikan panduan tentang pertolongan pertama pada keadaan darurat

b. Melakukan pemeriksaan santri secara berkala

c. Mencatat riwayat kesehatan santri selama berada di pondok pesantren

d. Mencatat riwayat penyakit yang pernah diderita oleh calon santri sebelum masuk di pondok pesantren

e. Merekomendasikan ke rumah sakit (jika diperlukan) dan membuatkan rujukan rumah sakit terkait

f. Memberikan obat sesuai dengan resep dokter

g. Melakukan pengecekan keadaan obat yang tersedia secara berkala

h. Penanganan terhadap santri yang sakit (rawat inap dan rawat jalan)

i. Menyediakan kotak P3K pada santri dan selalu mengecek kelengkapan dari kotak P3K tersebut.

\section{Sekretariat}

a. Melayani pendaftaran santri

b. Menyampaikan aturan yang ada di pondok pesantren

c. Melayani pengaduan baik dari santri ke orang tua maupun dari orang tua ke santri 
d. Mencatat tindakan pelanggaran yang dilakukan oleh santri

e. Melakukan komunikasi dengan santri

f. Membuat buku pedoman pelaksanaan tugas

g. Melakukan perekrutan staff baru dan penyimpanan dokumen staff baru

h. Melakukan pengenalan terhadap santri baru dan melakukan pendistribusian uang dari orang tua santri

i. Media penghubung antara santri dan orang tua (berkomunikasi lewat telepon atau surat)

j. Mencatat prestasi santri yang pernah diraih

k. Membuat laporan siswa yang sedang tidak berada di lingkungan pondok pesantren

1. Mengurus perizinan santri ketika keluar pondok pesantren

m. Memberikan infomasi kepada santri, staff dan orang tua santri

5. Asrama

a. Peribadatan (Kegiatan Asrama)

1) Melakukan kegiatan santri di pondok pesantren

2) Menyelenggarakan kegiatan dan melakukan seleksi terhadap peserta yang mengikuti kegiatan beresiko tinggi.

3) Melakukan bimbingan konseling untuk santri

4) Melakukan pelatihan untuk menangani wabah, kebakaran, kecelakaan dan masalah serius lainya.

5) Memberikan pengetahuan mengenai narkoba

b. Ekstrakurikuler

1) Mengadakan pelatihan kebakaran untuk seluruh pondok pesantren

2) Menjadwalkan kegiatan untuk santri diwaktu luang

3) Melakukan pengecekan terhadap fasilitas saat di waktu luang

4) Memberikan beberapa pilihan saat kegiatan waktu luang

6. Logistik dan Konsumsi

a. Menyedikan peralatan yang diperlukan oleh santri

b. Menyediakan tempat mencuci untuk santri

c. Melakukan pengecekan pada kelayakan fasilitas kesehatan pondok pesantren

d. Menyediakan dan memberikan prosedur kepada santri tentang ruang ganti

e. Mengganti fasilitas yang perlu diganti (tidak layak)

f. Melakukan pengecekan secara berkala pada fasilitas pondok pesantren (tempat cuci, kamar tidur, toilet, klinik, ruang belajar)

g. Melakukan penyimpanan bahan makanan

h. Mengolah, memasak dan menyediakan makanan sesuai dengan kebutuhan santri (sesuai gizi)

i. Membedakan fasilitas yang diberikan untuk santri putra dan santri putri

\section{STRUKTUR ORGANISASI}

Dari SOP dan juga Jobdesc yang telah dibuat berdasarkan 52 standar pondok pesantren maka diperoleh struktur organisasi seperti berikut

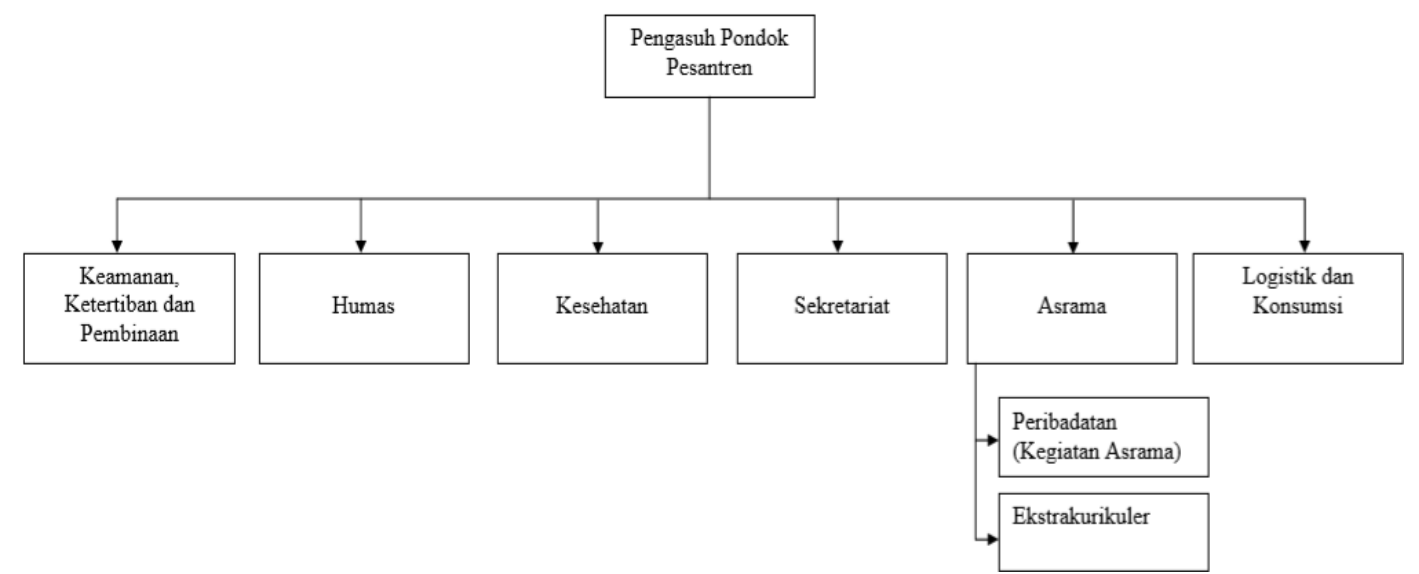

Gambar 3. Struktur Organisasi 


\section{SIMPULAN}

Pengembangan arsitektur enterprise adalah dasar bagi institusi pondok pesantren. Pengembangan arsitektur bisnis pondok pesantren ini menggunakan TOGAF ADM sebagai standar pengembangan arsitektur enterprise karena TOGAF ADM merupakan metode pengembangan arsitektur enterprise yang bisa disesuaikan dengan kebutuhan, dengan syarat bahwa institusi mempunyai aturan dan prosedur yang jelas tentang proses bisnis untuk mendukung proses pengembangan sistem informasi terintegrasi. Pondok pesantren memiliki 52 standart, dari 52 standart akan dibuat Model Proses Bisnis/SOP dan JOB Descripsion maka akan memperoleh struktur organisasi dari 52 standart tersebut. Pada penelitian ini, peneliti menggunakan website artikata.com untuk mencari kesamaan makna kata pada SOP yang telah dibuat dan menggunakan algoritma TF-IDF (Term Frequency - Inverse Document Frequency) untuk melakukan pengelompokkan antar kalimat dari Model Proses Bisnis/SOP tersebut.

\section{SARAN}

Berdasarkan dengan penelitian yang telah dilakukan. Penelitian ini perlu dikembangkan lagi dengan menggunakan metode yang lain untuk memaksimalkan pembuatan model proses bisnis pondok pesantren yang lebih terstruktur dan komplek..

\section{DAFTAR PUSTAKA}

[1] Suhendri. Perancangan Arsitektur Sistem Informasi Sekolah dengan The Open Group Architecture Framework (Togaf). Infotech Journal. 2015

[2] Sutono. Pemodelan Arsitektur Enterprise Pada Sekolah Menengah Atas Menggunakan Enterprise Architecture Planning. Magister Sistem Informasi Universitas Komputer Indonesia 2015. DOI: https://doi.org/10.33867/jtk3ti.v1i2.297

[3] Kurniawan Riza. 2013. Perancangan Arsitektur Enterprise Pada Pondok Pesantren Salafiyah Syafi'yah Situbondo dengan Standart Togaf. Skripsi. Tidak Diterbitkan. Fakultas Sains dan Teknologi. Universitas Maulana Malik Ibrahim Malang.

[4] Hakim Robie. 2013. Perancangan Blue Print Pengembangan Sistem Informasi Pesantren Menggunakan Zachman Framework (Studi Kasus Pondok Pesantren Wahid Hasyim Yogyakarta). Skripsi. Tidak Diterbitkan. Fakultas Sains dan Teknologi. Universitas Uin Sunan Kalijaga Yogyakarta.

[5] Yunis, Roni, dkk. Arsitektur Bisnis: Pemodelan Proses Bisnis dengan Object Oriented. UPN "Veteran" Yogyakarta: 2010 